\title{
Pattern of Ear Diseases among Paediatric ENT Patient: An Experience from Tertiary Care Centre, Pokhara, Nepal
}

\author{
Sigdel B ${ }^{1}$, Nepali $\mathbf{R}^{2}$ \\ ${ }^{1}$ Dr. Brihaspati Sigdel, MBBS, MS, Assistant Professor, ${ }^{2}$ Dr. Rajendra Nepali, MBBS, MS, Lecturer. Both from the department \\ of Otorhino Largology (ENT) Gandaki Medical College, Pokhara, Nepal.
}

Address for correspondence: Dr. Brihaspati Sigdel, E-mail: brihassig@yahoo.com

\begin{abstract}
Introduction: Ear diseases are common in children mainly due to altered anatomy of Eustachian tube which is straighter in children as compared to that in adults. However, the cause of hearing loss in children is more varied, including the etiologies. This study was done to find out the pattern of ear diseases in paediatric age group attending ear, nose and throat OPD in a tertiary care centre in Pokhara, Nepal. Materials and Methods: This is a prospective study done in paediatric patients attending ENT OPD over a period of one year from January 2010 to January 2011. The diagnoses were made on the basis of history and clinical examination. Results were expressed in numbers and percentages. Results: Out of 1632 Pediatric ENT patients, 944 had ear diseases, 59.2\% were males and 40.8\% females. Wax (33.4\%) was the commonest diagnosis followed by Chronic suppurative otitis media (24.3\%) and Acute ottitis media (13\%). Conclusion: Ear diseases are most common condition in ENT OPD among paediatric age group. Wax, CSOM and ASOM were the three most common ear diseases.
\end{abstract}

Key words: ASOM, CSOM, Paediatric ear disease, wax.

\section{Introduction}

$\mathrm{N}$ epal is a landlocked country located in South Asia, surrounded by Himalayas and bordered by China and India. Majority of Nepalese people rely on agriculture. The population of Nepal is approximately 30 million'. Population below the age of 14 years is $34.6 \%{ }^{2}$.

Health is vital for overall development of a child and determines his/her ability to acquire knowledge and skill. Otitis media is the most common disease in children mainly due to altered anatomy of Eustachian tube which is straighter in children as compared to that in adults ${ }^{3}$. However, the cause of hearing loss in children is more varied, including the etiologies.

In the Nepalese context, approximately $16 \%$ of the population above the age of 5 years suffer from otitis media. More than $55 \%$ of these cases occur in school going children, most of them belonging to the lower socio-economic class ${ }^{4}$.

Manuscript received: $7^{\text {th }}$ January 2012

Reviewed: $3^{\text {rd }}$ April 2012

Author Corrected: $5^{\text {th }}$ April 2012

Accepted for Publication: $30^{\text {th }}$ April 2012
The aim of this study was to find out the pattern of ear diseases in paediatric ENT patients in a tertiary care centre of Pokhara, Nepal.

\section{Materials and Methods}

This hospital-based prospective study was carried out between January 2010 to January 2011 in the Ear, Nose and Throat (ENT) Department, Gandaki Medical College, Pokhara, Nepal. All patients aged 16 years or younger presenting with ear diseases to the ENT clinic of the hospital and seen by ENT surgeons were enrolled into the study. The information included demographic data like age, sex, and history of ear disease was noted, and physical examination was also done. Otoscopic examination was done using Welch Allyn otoscope REF 71045 (USA).

Wax obstructing at least one quadrant of pars tensa was considered as significant and included in the study. It was considered impacted when the wax covered the whole of external auditory canal and tympanic membranewas not visibleatall. Chronic suppurative otitis media implies to a permanent abnormality of the pars tensa or pars flaccida. Acute otitis media was diagnosed 
with either history of earache, fever, impaired hearing or otorrhoea and examination of tympanic membrane showing intensely red or bulging or perforation. Cases were diagnosed as otitis media with effusion if there was visible retraction and change in colour (dull) of tympanic membrane and its mobility on pneumatic otoscopy. The study proposal was reviewed and approved by Gandaki Medical College Charak Hospital Ethical committee. After getting approval from the ethical committee of our institution, informed consent was taken from guardians participating in this study. Results were expressed in numbers and percentages.

\section{Results}

1632 patients below sixteen years of age presented to the ENT OPD during the study period. Of them, 944 had ear disease. Five hundred and sixty one (59.2\%) were males. The male to female sex ratio was 1.5:1.

Age and sex distribution are given as in Table1 and the various types of ear disease are as in Table 2.

CSOM(Chronic Suppurative Ottitis Media), ASOM(Acute Suppurative Ottitis Media), OME(Ottitis Media with Effusion).

Table 1: Showing the Age and Sex distribution of patients with ear diseases.

\begin{tabular}{|c|c|c|c|}
\hline $\begin{array}{c}\text { Age } \\
\text { (Years) }\end{array}$ & Male & Female & Total (\%) \\
\hline $0-5$ & 114 & 80 & $194(20.6 \%)$ \\
\hline $6-10$ & 239 & 173 & $412(43.6 \%)$ \\
\hline $11-16$ & 208 & 130 & $338(35.8 \%)$ \\
\hline Total & $\mathbf{5 6 1 ( 5 9 . 2 \% )}$ & $\mathbf{3 8 3 ( 4 0 . 8 \% )}$ & $\mathbf{9 4 4 ( 1 0 0 \% )}$ \\
\hline
\end{tabular}

\section{Discussion}

Ear disease is one of the major public health problems in developing countries. Wax (33.4.\%) followed by CSOM (24.3\%) and ASOM (13.0\%) were the most common ear diseases in paediatric patients in tertiary care centre. Ear diseases commonly found in this study were in the age group of 6-10 years and most ear diseases were more common in boys.

It was found that wax (33.4\%) was the most common diagnosed ear disease. Even though our hospital is located in the city, it covers the rural hilly region where most of villages don't have facilities like syringing, suctioning and hook wax removal. Adhikari et $\mathrm{al}^{5}$ found that wax impaction is the most common finding in paediatric population attending health camps in Nepal (62\%), however Okafor ${ }^{6}$ in his study found wax impaction to be the third most common ear disease in the southeastern part of Nigeria. Hatcher et $\mathrm{al}^{7}$, Elango et $\mathrm{al}^{8}$ and Minza et $\mathrm{al}^{9}$ reported prevalence rates of impacted wax ranging from $8.6 \%$ to $28.2 \%$. It is said that humidity, temperature and racial differences play an important role in wax production and impaction. Impacted wax is mostly a silent condition and may not have been attended by the caregivers of the children at school age and possibly had influence even on hearing. Jacob et $\mathrm{al}^{10}$ and Sharma et $\mathrm{al}^{11}$ reported wax as the most common cause of hearing impairment, which accounted for $29.8 \%$ and $50.0 \%$ of cases respectively. Hearing impairment was not assessed in this study; thus the possible influence of hearing due to wax could not be ascertained.

Chronic suppurative otitis media (CSOM) is a major health problem in developing countries throughout the world. It is the most common cause of persistent mild to moderate hearing impairment in children and young adults $^{12}$. High rates of CSOM have been attributed to overcrowding, inadequate rates of nasopharyngeal colonization with potentially pathogenic bacteria and inadequate or unavailable health care. Poverty is a major risk factor in developing countries and certain negelected populations ${ }^{13}$. This study showed that $23.4 \%$ of children had CSOM. $72 \%$ had CSOM tubotympanic type and $28 \%$ had Attico-antral disease. The prevalence of CSOM was $6 \%$ as found by Rupa et $\mathrm{al}^{14}$, Biswas et

Table 2: Showing the various types of ear diseases according to age in children having ear disease.

\begin{tabular}{|l|c|c|c|c|c|r|}
\hline \multicolumn{1}{|c|}{ Disease } & Male & Female & $\mathbf{0 - 5 y r s}$ & $\mathbf{6 - 1 0 y r s}$ & $\mathbf{1 1 - 1 6 y r s}$ & Total (\%) \\
\hline Wax & 189 & 126 & 44 & 167 & 104 & $315(33.4 \%)$ \\
\hline CSOM & 139 & 90 & 45 & 98 & 86 & $229(24.3 \%)$ \\
\hline ASOM & 70 & 53 & 45 & 39 & 39 & $123(13 \%)$ \\
\hline OME & 48 & 41 & 30 & 35 & 24 & $89(9.4 \%)$ \\
\hline Ottitis Externa & 45 & 36 & 12 & 32 & 37 & $81(8.6 \%)$ \\
\hline Otomycosis & 30 & 14 & 4 & 13 & 27 & $44(4.7 \%)$ \\
\hline Foreign Body & 14 & 8 & 4 & 12 & 6 & $22(2.3 \%)$ \\
\hline Preauricular Sinus & 8 & 5 & 5 & 4 & 4 & $13(1.4 \%)$ \\
\hline Others & 18 & 10 & 5 & 12 & 11 & $28(3 \%)$ \\
\hline \multicolumn{1}{r|}{ Total } & $\mathbf{5 6 1}$ & $\mathbf{3 8 3}$ & $\mathbf{1 9 4}$ & $\mathbf{4 1 2}$ & $\mathbf{3 3 8}$ & $\mathbf{9 4 4 ( 1 0 0 \% )}$ \\
\hline
\end{tabular}


al $12.4 \%^{12}$, Maharjan et al $13.2 \%^{15}$, and Akinpelu et al $33.9 \%{ }^{16}$. Most of these studies were done in school children but our study was based on patients attending the hospital. Sixty-five to $95 \%$ of children would have suffered one or more attacks of acute suppurative otitis media or acute otitis media (ASOM/AOM) before the age of 7 years ${ }^{17}$. ASOM was the third most common ear diseases in our study and accounted for $13.0 \%$ of them all. Similarly it was also the third most common ear disease in the study done by Akinpelu and Amusa et al, however the frequency was lower $(7.0 \%)^{16}$.

Otitis media with effusion (OME) is one of the most common causes of hearing impairment and one of the most frequent reasons for elective admission to hospital for surgery during childhood in the western world. According to the study done by Adhikari et $\mathrm{al}^{5}$ the prevalence among rural Nepalese school children was $4.7 \%$. Study done in Nigeria revealed that $5.3 \%$ of children had $\mathrm{OME}^{16}$. The study found that $9.4 \%$ of cases had OME but Kishve et al found it to be in $20 \%$ in a rural medical college in India ${ }^{18}$.

Otitis externa, otomycosis, and preauricular sinus are the least common diseases in descending order in our study. Our study showed $57.8 \%$ of paediatric ENT patients had ear diseases which is comparable to the study done by Awan Z et al $(47 \%)^{19}$. This being of a small sample size and single centred study, might not reflect the actual prevalence and pattern of ear diseases as a whole. Multicentred and large sample sized study is further needed to find out the actual prevalence and pattern of ear diseases in this country.

\section{Conclusion}

Ear diseases are one of the major health problems among children of Nepal. Wax followed by chronic suppurative otitis media and acute otitis media were the most common ear diseases in children attending the paediatric ENT OPD. Increasing awareness about ear diseases should be one of the goals of all health care providers. Improvement of health care facilities and awareness amongst health care providers would definitely be helpful in reducing the prevalence of ear diseases in developing countries like Nepal.

Acknowledgements: The author would like to acknowledge all the children who participated in this study.

\footnotetext{
Funding: Nil

Conflict of Interest: None

Permission from IRB: Yes
}

\section{References}

1. The World Fact book: Nepal. (http://www.cia,gov/ library/publications/the-world-factbook/print/ np.html.). Accessed: 23 February 2012

2. Government of Nepal. Central Bureau of Statistics. Statistical Year Book of Nepal, 2009.Kathmandu. (http://www.cbs.gov.np/Year_Book_2009/images/ Final_Chapters/chapter1/1.7.pdf.). Accessed 23 February 2012.

3. Finnbogadottir AF, Petersen $H$, Laxdal $T$, Gudbrandsson F, Gudnason T, Haraldsson A. Mastoiditis in children in Iceland. Laeknabladid 2007;93:275-80.

4. About hearing Nepal. Hearing Nepal programme, 2010.( http://hearingnepal.org/about/)

5. Adhikari P. Pattern of ear diseases in rural school children: Experiences of free health camps in Nepal. Int J Pediatr Otorhinolaryngol 2009;73:1278-80.

6. Okafor BC. Otolaryngology in Southeastern Nigeria: pattern of diseases of the ear. Nigeria Med J 1983;13:11-19.

7. Hatcher J, Smith A, Mackenzie I, Thompson S, Bal I,Macharia I et al. A prevalence study of ear problems in school children in Kiambu district, Kenya, May 1992. Int J Pediatr Otorhinolaryngol 1995;33:197-205.

8. Elango S, Purohit GN, Hashim M, Hilmi R. Hearing loss and ear disorders in Malaysian school children. Int J Pediatr Otorhinolaryngol 1991;22:75-80.

9. Minja BM and Machemba A. Prevalence of otitis media, hearing impairment and cerumen impaction among schoolchildren in rural and urban Dar es Salaam, Tanzania. Int J Pediatr Otorhinolaryngol 1996;37:29-34.

10. Jacob A, RupaV, Job A, Joseph A. Hearing impairment and otitis media in a rural primary school in South India. Int J Pediatr Otorhinolaryngol 997;39:133-38.

11. Sharma H, Bhusan V, Dayal D, Mishra SC. Preliminary study of hearing handicap in school-going children. Indian J Otolaryngol Head Neck Surg 1992;30:1 19-24.

12. Biswas $A C$, Joarder $A H$, Siddiquee $B H$. Prevalence of CSOM among rural school going children. Mymensingh Med J 2005;14:152-55.

13. Prevention of Hearing impairment from chronic otitis media, WHO/CIBA Foundation Workshop Report, London 1996, 19-21.

14. Rupa V, Jacob A, Joseph A. Chronic suppurative otitis media: prevalence and practices among rural 
south Indian children. Int J Pediatr Otorhinolaryngol 1999;48:217-21.

15. Maharjan $M$, Bhandari S, Singh I, Mishra SC. Prevalence of otitis media in school going children in eastern Nepal. Kathmandu Univ Med J 2006;16:47982.

16. Akinpelu OV, Amusa YB. Otological diseases in Nigerian children. Int J Otorhinolaryngol 2007;7:1.

17. Claessen JQPJ, Appelman CLM, Toluw-otten FWM, de Meeker RA, Hordijik GJ. A review of clinical trials regarding treatment of acute otitis media. Clin Otolaryngol 1992;17:251-57.

18. Kishve SP, Kumar N, Kishve PS, Syed MMA, Kalakoti P. Ear, Nose and Throat disorders in paediatric patients at a rural hospital in India. Australasian Med J 2010;12:786-90.

19. Awan Z, Hussain A, Bashir H. Statistical analysis of ear, nose and throat(ENT) diseases in paediatric population at PIMS,Islamabad:10 years experiences. J Med Sci 2009;17:92-94.

\section{How to cite this article ?}

Sigdel B, Nepali R. Pattern of Ear Diseases among Paediatric ENT Patient: An Experience from Tertiary Care Centre, Pokhara, Nepal. J Nepal Paediatr Soc 2012;32(2):142-145. 